\title{
Indonesia's Effort to Improve Islamic Images in The United States During 2009-2017: A Case Study of Interfaith Dialogue
}

\author{
Hendra Maujana Saragih, Esca Hutama Prayogo Surya, \\ Syifa Nur Islamiah \\ Universitas Nasional, Jakarta, Indonesia \\ hendramaujana@gmail.com
}

\begin{abstract}
Indonesia strives to improve the Islamic image in the United States during the year of 2009-2017. As an effort, Indonesia conducted interfaith dialogue as a diplomacy instrument with the United States known as the Indonesia-US Interfaith Dialogue. As regards the interfaith dialogue, the researchers then scrutinized the efforts of Indonesia to improve the Islamic image in the United States. The researchers used two concepts and one theory in this study, precisely the concept of national interests, the concept of foreign policy, and the concept of Public Diplomacy. This study applied a qualitative approach. The secondary data were taken from books, journals, theses, and official websites and news. The results of this study revealed that after conducting an Interfaith Dialogue with the United States during 2009-2017, the Islamic image in the United States raised to be positive. The positive's improvement could be seen in US leaders who understood the true meaning of Islam in which Islam is a religion that brought peace as what was promoted by Indonesia.
\end{abstract}

Keywords: Interfaith Dialogue, Islamophobia

\section{Introduction}

In international conflicts, the attention is no longer focusing on the high politics that includes national security and military issues but instead focuses on low politics issues. It attacks non-traditional security issues such as the environment, the spread of diseases, transnational crime, and other contemporary issues threatening global peace. In addition, the conflicts' issues of communal identity that are commonly based on religion, ethnicity, race, clan, ethnicity, or other identities become a factor of international conflict. ${ }^{1}$ Today, political actors use and uphold faith or religion as their weapons to participate in international politics. However, they occasionally have mis conceptions about the religion associated with crimes such as Islam which currently linked

${ }^{1}$ Andi Purwono. "Organisasi Keagamaan dan Keamanan Internasional : Beberapa Prinsip dan Praktik Diplomasi Nahdlatul Ulama (NU) Indonesia." Jurnal Politik Profetik: Vol. 2 No.2, 2013, page. 1.

AJIS : Academic Journal of Islamic Studies, vol. 5, no. 1, 2020

IAIN Curup - Indonesia | ISSN 2580-3174, (p); 2580-3190 (e)

DOI: $10.29240 / a j i s . v 5 i 1.1351$, page: $1-20$ 
to acts of terrorism. Unfortunately, it causes a bad image for Islam as a radical religion. In the concept of Islam, the relationship between individuals and nations is a relationship of peace in which as social human beings, we need to interact with other humans to fulfill life's needs. Considering as a perfect life system, Islam has given the ways to convey the peace of human life in the world. $^{2}$

The spread of Islam in the United States began with the first entry of Islamic teachings into the Americas through immigrants from Syria in 18751912. Afterward, several waves of immigration from Islamic populations such as African, Middle Eastern states, Eastern Europe, and Asia migrated to the United States. ${ }^{3}$ The United States then issued immigration laws regarding the right to enter the country regardless of race or religion. Thus, the contemporary United States can be said to be a state of pluralism. ${ }^{4}$

On September 11th, 2001, the hijacking of a US aircraft allegedly carried out by a hard-line Islamic terrorist group called Al-Qaeda headed by Osama Bin Laden, crashed a plane into the World Trade Center (WTC) in New York and the Pentagon in Washington. This event is then called 911. After this incident, US President George W. Bush, along with politicians and the US CIA, made stereotypes about Islam relating to acts of terrorism. Furthermore, the US made a policy of war on terrorism, a policy to attack Al-Qaeda and Osama Bin Laden in Afghanistan. After 911, US media continued to preach a negative image of Islam to the public in both their country and internationally, ${ }^{5}$ The term Islamophobia then was born among the western countries with a negative view of Islam.

Islamophobia is defined as a fear and anxiety experienced by a person or social group against the teachings of the religion of Islam and its adherents. Moreover, Islam is considered as a religion that is low and inappropriate to influence the values that exist in society, especially the US. ${ }^{6}$ Until now, in the era of President Donald Trump, Islamophobia is still felt by the US public. Trump issued a policy to ban the entry of immigrants from

\footnotetext{
${ }^{2}$ Abizal Muh. Yati. "Islam dan Kedamaian Dunia”. Islam Futura : Vol. VI No.2, 2007. page. 13.

${ }^{3}$ Khalik, Subehan. "Sejarah Perkembangan Islam di Amerika." Al Daulah : Vol. 4 No.2, 2015, Page. 317

${ }^{4}$ Ibid. Page. 319.

5Ema Khotimah. "Bias Ideologis dan Prasangka Agama Pada Terorisme dan Media Massa." Jurnal Agama : Vol. XIX No.04, 2003. pagesl. 347-350.

6Moordiningsih, "Islamophobia dan Strategi Mengatasinya." Buletin Psikologi : Tahun XII No.2, 2004 page. 75.
} 
Hendra Maujana Saragih, et.al: Indonesia's Effort to Improve Islamic Images | 3

seven Middle Eastern and African Islamic countries to maintain safety in the US. $^{7}$

Previous research entitled Moderate Islamic Identity in Indonesian Foreign Policy (2004-2011) explained that Indonesia is not a country that is built by religious similarity but by national pluralism and religious pluralism that is bound by the Pancasila ideology as the basis of the state. The recognition of pluralism has influenced the pattern of Indonesia's foreign policy. During the Soekarno and Suharto governments, foreign policy was carefully monitored not to be dictated by considerations of Islamic ideology. It is intended to maintain communal religious feelings so as not to damage national unity. However, the Department of Foreign Affairs began promoting Indonesia's moderate Islamic identity since 2004. Minister of Foreign Affairs, Hassan Wirajuda explained, as the country with the largest Muslim population in the world, Indonesia bears the obligation to project the real face of Islam, namely Islam moderate. Through various international forums and conferences, Indonesia is trying to prove that Islam, modernity, and democracy can go hand in hand with one another. This moderate expression of Indonesian Islam can at least be found on several occasions, such as in the Bali Democracy Forum (BDF), the World Movement for Democracy, the Parliamentary Union of OIC Member States (PUIC), and the International Conference on Global Movement of Moderates. It confirms that Indonesia's foreign policy is no longer allergic to the elements of Islam in portraying Indonesia's national identity on the international level. Placement of moderate Islamic identity as an essential dimension in national imaging indicates Indonesia's desire to display its uniqueness amid international relations. ${ }^{8}$

According to this issue, it was found that the previous research was conducted to understand the specific arguments of the government elite in taking moderate Islamic identity preferences in the formulation of Indonesia's foreign policy in 2004-2011. This present study, on the other hand, was conducted to determine the implementation of Indonesia's Islamic moderate foreign policy towards the United States, which is in the form of Interfaith Dialogue or interfaith dialogue during 2010-2017. This study aims to find out

${ }^{7}$ Jawahir Tontowi. "Kebijakan Presiden Trump dan respon Masyarakatnya Terhadap Larangan Muslim Arab Tinggal di Amerika." Jurnal Hukum IUS QUIA IUSTUM No. 3 Vol. 24, 2017, Page. 378.

${ }^{8}$ Lelly Andriasanti, "Identitas Islam Moderat Dalam Kebijakan Luar Neger Indonesia." Global : Universitas Agustus 1945 Jakarta Paper.Vol. 16 No. 1 2014. Pages. 13. 
the extent of religious diplomacy carried out by the government and nongovernmental actors in the following year after the beginning of the dialogue in 2004. It took efforts to improve Islamic image, which was underestimated by western countries because Islam is a tolerant and peace-loving religion and not a radical religion and. Moreover, this study aims at finding out the history, impact, and factors of Islamophobia in the United States. With the new face of Islam that began with the religious diplomacy carried out in 2004, Indonesia hopes to achieve its national interest, so that western countries do not see Islam as a radical religion but a tolerant and peace-loving religion.

Indonesia, as a country that embraces most religions, did not remain silent seeing the bad image of Islam in western countries, especially the US. Given the bilateral relations between Indonesia and the US have been established since Indonesia's independence until now, ${ }^{9}$ Indonesia made an effort to improve the negative image of Islam in the US, which was initially a negative image of Islam created and spread by the US for the dominance of the liberation power and power of this contemporary era. In response to the aftermath of the 911 tragedy that caused a bad image of Islam in the United States, Indonesia sought to become a media link or bridge between the West and Islam by spreading the understanding through Indonesian foreign policy so-called moderate Islam.

In the era of Indonesia's presidential leadership, after the 911 tragedy, Megawati at that time, gave a speech in Indonesia and also visited the US and met George W Bush as president of the United States. Megawati conducted an Interfaith Dialogue, ${ }^{10}$ and also stated that Indonesia did not agree with the US military invasion of Afghanistan to fight terrorists who the United States considered Islamic terrorists. ${ }^{11}$ Furthermore, Susilo Bambang Yudhoyono as president of Indonesia made a statement to create a foreign policy of moderate Islamic Indonesia. This foreign policy aimed to make Indonesia as a model of an Islamic state that modernized and upheld democracy. ${ }^{12}$ In addition to the other objectives of Indonesia's moderate Islamic foreign policy,

${ }^{9}$ Embassy of Indonesia. "Brief History Bilateral Relations United States and Indonesia". accessed http://www.embassyofindonesia.org/index.php/bilateral-relations/on July $30^{\text {th }}, 2019$.

10 M. Muttaqien, Studi Strategis Indonesia II: Politik Luar Negeri Republik Indonesia. Page. 110.

${ }^{11}$ Rizal Sukma, Islam in Indonesian Foreign Policy. RoutledgeCurzon. Page.134.

${ }^{12}$ Ziyad Falahi, "Signifikansi Diplomasi Islam Moderat Era Susilo Bambang Yudhoyono dalam Merespon Problem Timur Tengah." Andalas Journal Of International Relations No.1 Vol.2, 2013, Page. 33. 
it is to image Indonesia by distinguishing itself from the radical impression of other Arab countries. ${ }^{13}$

In response to the poor image of Islam in the US, starting from 2004 Indonesia conducted interfaith dialogue with the US. ${ }^{14}$ The objective of Interfaith Dialogue is to improve the image of Islam in the United States and also to support the understanding between the United States and world Muslims' communities. The interfaith dialogue activity which was promoted by Indonesia, was also targeted to counter negative stereotypes about Islam that developed in the West, especially the United States. There was an assumption that Islam was behind various acts of terrorism. ${ }^{15}$ It is also considered important to dispel suspicions and misunderstandings between religions and cultures, and otherwise promote harmony and cooperation between Indonesia and the US.

Since 2009, Indonesia and the US have an Interfaith Dialogue collaboration program. ${ }^{16}$ Secondly these countries signed a cooperation agreement the Peac Corps, where the two countries announced the implementation of the Interfaith Dialogue and the presence of IndonesiaUS Interfaith Cooperation. ${ }^{17}$ In detail, Interfaith Dialogue is defined as an implementation of Indonesia's moderate Islamic foreign policy in the form of Diplomacy conducted by the Indonesian president, the foreign ministry and Indonesian religious leaders. Interfaith Dialogue is the output of Indonesia's independent foreign policy which actively participates as a bridge between the western world and Islam.

Anchored in the background above, the authors then conducted a research on "Interfaith Dialogue" as Indonesia's efforts in the form of Indonesian Diplomacy to improve the image of Islam in the United States".

This study applied qualitative approach. Bogdan and Taylor (1975) defined qualitative methodologies as research procedures that produce

\footnotetext{
${ }^{13}$ Lelly Andriasanti,Op.Cit.Pages. 89-91.

14 Kementrian Agama. "Dasar Pemikiran Interfaith Dialogue." Accessed https://pkub.kemenag.go.id/artikel/17866/dasar-pemikiran-interfaith-dialogueon June 17th, 2019.

${ }^{15}$ Ibid.

${ }^{16}$ Kementrian Luar Negeri. "Hubungan Bilateral Indonesia-Amerika Serikat." Accessed https://kemlu.go.id/washington/id/pages/hubungan_bilateral/554/etc-menuon June 17th, 2019.

17 Kementrian Luar Negeri. "RI-AS Sepakati Kerjasama Peace Corps dan Interfaith Dialogue." Accessed https://ex.kemlu.go.id/id/berita/siaran-pers/Pages/RI-ASSepakati-Kerjasama-i-Peace-Corps-i-dan-i-Interfaith-Dialogue-i.aspxon June 17th, 2019.
} 
descriptive data in the form of written or oral words from people and observable behavior. According to them, the qualitative approach is directed at the individual's setting holistically (whole). Hence, in this case it is not allowed to isolate individuals or organizations into variables or hypotheses, but it is necessary to view them as part of comprehensiveness. ${ }^{18}$

Qualitative research is an approach that uses data in the form of sentences, schematics, pictures, tables and diagrams that serve to strengthen the arguments that will be used in research. ${ }^{19}$ This study was done by looking at the existing problems associated with your later theories in the study of international relations. The source of data used in this study was a type of secondary data source. ${ }^{20}$ Secondary data source is data obtained from written sources consisting of books and journals, the source of the archive's private documents and official, journals, and feed the results of studies such as dissertation or thesis, a study of history and the internet in the form of ejournal, e-book, website, and others. The written secondary data sources have been published by either government or non-government institutions and also by the results of someone's work. ${ }^{21}$

\section{The Concept of National Interest}

According to Hans J. Morgenthau the national interest of a country is aimed to pursue power, that is, anything that can form and maintain a country's control over another country. That power and control relationship can be created through coercive techniques or cooperation.22 In the national interest, the role of the state is as an actor who takes decisions and plays an important role in influencing international relations for the people in his country. It is so important because it gives the benefit to the people who live in the region. An expert, Thomas Hobbes concluded that the state was seen as a protector of the region, population, and a unique and valuable way of life.

18 Lexy J. Moleong. Metodologi Penelitian Kualitatif, Bandung: Remaja rosdakarya, Cet 33, 2014. Page. 4.

${ }^{19}$ Lisa Harison, Metode Penelitian Politik, Jakarta: Kencana, 2007.

${ }^{20}$ Mochtar Mas'oed, Ilmu Hubungan Internasional : Disiplin dan Metodologi, Jakarta: LP3ES, 1990. Page. 223.

${ }^{21}$ Lexy J. Moleong, Op.Cit Page. 159.

22 Mochtar Mas'oed, Ilmu hubungan Internasional; Disiplin dan Metodologi, Ulasan tentang Morgenthau mengenai Konsep Kepentingan Nasional, Jakarta: PT. Pustaka LP3ES, 1990. Page.139. 
National interests are created from the needs of a country, these interests can be seen from the internal conditions, the political-economic condition, military, and socio-cultural. National interests also constituted as power to be created so that the state can provide an immediate impact for the consideration of the country to the world's recognition. ${ }^{23}$ The role of a country in providing material as a basis of national interests will undoubtedly become the lens of the international community as a country that establishes relations attached to its foreign policy. Appertaining to this issue, the national interest is conceptually used to explain the behavior of foreign policy of a country. ${ }^{24}$

Hans J. Morgenthau also stated that national interests are the minimum ability of countries to protect and maintain physical, political, and cultural identity from interference from other countries. Based on that review, the leaders of a country can reduce a specific policy towards other countries that are both cooperation and conflict. The existence of national interests illustrates that there are aspects that become the identity of the state. It can be seen from the extent to which the focus of the state in meeting the achievement targets for the survival of the nation. By using the created identity, it can be formulated what are the targets in the near future, temporary or also for the sake of longterm sustainability. This also goes along with how important the identity is, whether it is very important or not.

\section{Foreign Policy Theory}

Foreign policy is determined by four determinants, namely the international context, the behavior of foreign political decision makers, the impact of economic and military conditions on a country, and the role of domestic politics in the formulation of foreign policy. ${ }^{25}$ Politics are closely linked with a series of policies and the order rules that aim to regulate the affairs of state.

A foreign policy, which is one part of politics' world, then becomes one of the platforms that can help a country to achieve its various interests. The national interest itself is a guide for implementing foreign policy. It can be interpreted as the interests of the state as a unitaryactor that

${ }^{23}$ P. Anthonius, Sitepu, Studi Hubungan Internasional, Yogyakarta: Graha Ilmu, 2011. Page. 163.

${ }^{24}$ Ibid.

${ }^{25}$ William, D. Coplin, Pengantar Politik Internasional, Bandung: CV. Sinar Baru, 1990. dikutip oleh Sri, Winingsih. "Kebijakan Luar Negeri Amerika Serikat Terhadap Program Nuklir Iran,” Skripsi, Universitas Indonesia, 2009. Page. 6. 
emphasize on increasing national power to maintain national security and the ability for survival of the country. ${ }^{26}$

Universally, according to Kenneth N. Waltz, the matters contained in foreign policy theory are related to a particular country and its motivations, policies, decrees, and behavior by referring to global problems. ${ }^{27}$ In this case, foreign policy is not only related to policies themselves, but can also be implemented in responding to the issues that occur in the international world.

In general, a country's foreign policy is divided into two, namely directed towards a particular country or issue and universal or general. The volatility of foreign policy is determined by the objectives to be achieved. Policy abroad is a strategy or plan of action developed by the state decision-makers in the front of other countries or other international political units and controlled to achieve specific national goals as outlined in terms of national interest. $^{28}$

In formulating its moderate Islamic foreign policy originates from Indonesia's soft power, namely pluralism between religious communities, Indonesia sees Islam as an Indonesian identity that can be packaged into a foreign policy to achieve its national interests, making Indonesia a role model of a successful democracy and became a bridge between the West and Islam.

\section{The Concept of Public Diplomacy}

Diplomacy in general, is often associated with processes, activities, and negotiations carried out peacefully by one country in establishing relations with other countries with a purpose to achieving its national goals. "Diplomacy is peaceable coercion to promote the interest of the state and nation". ${ }^{29}$

According to Sir Ernest Satow, diplomacy is the application of intelligence and tactics to carry out official relations between sovereign governments. The state through official representation and other actors seeks to convey, coordinate and exclusive secure, or broader national interests. It is

${ }^{26}$ Abdul, Mutholib A. "Kepentingan China Dalam Konflik Suriah. Skripsi, Universitas Hasanuddin, Makassar, 2013.

${ }^{27}$ Asrudin, Mirza Jaka Suryana, Refleksi Teori Hubungan Internasional Dari Tradisional ke Temporer, Yogyakarta: Graha Ilmu, 2009. Page. 26.

${ }^{28}$ Jack C. Plano, Roy Olton, Kamus Hubungan Internasional Bandung: Abardin, 1999. Page. 5.

${ }^{29}$ Freeman, Chas. The Diplomat's Diary, National Defense: University Press. 2006. Page. 72 accessed https://e-journal.unair.ac.id/JGS/article/view/6915 on December $11^{\text {th }}, 2018$. 
carried out through correspondence, informal talks, exchanging perspectives, lobbying, visiting and peaceful activities. It can also occur in conditions of war or armed conflict, because the main task of diplomacy is not only conflict management but also management of change and its maintenance by carrying out persuasion amid ongoing change. ${ }^{30}$ The primary function of Diplomacy is to resolve various international differences in a calm and friendly way through discussion and negotiation, which involves good relations and mutual understanding. Interfaith Dialogue is a form of Indonesiadiplomacy operations that make use of faith as an instrument. There was a discussion to find a compromise point of the various beliefs' values. As a result, it can become a platform for efforts toward harmony among civilizations, especially interfaith harmony that is anti-thesis views about the clash of civilizations belong to Huntington.

Moreover, Public Diplomacy is defined as an effort to achieve the interests of a country through understanding, informing and influencing foreign audiences. It is different from traditional diplomacy which means the relationship of government to government. Public diplomacy is more emphasis on the link of government to people or people to people. Through public diplomacy, the public can support government policy and influence the international public opinion about the country. ${ }^{31}$

Public diplomacy aims to create an understanding of communication between international actors and build a positive image of a country towards other countries through an interaction between interest groups. Public diplomacy is carried out with the aim that domestic and international communities have a good perception of the activities or actions of the state, as a social foundation for broader relations and achievement of interests. Interfaith dialogue as second track diplomacy, carried out by Indonesia against the United States as an effort to give an understanding that Islam is not a religion of terrorism. Conversely, Islam is a religion that is easily integrated with culture and democracy as it is in Indonesia.

${ }^{30}$ Sukawarsini, Djelantik. Diplomasi: Antara Teori dan Praktik. Yogyakarta: Graha Ilmu, 2008. Page. 1.

31 Papp, Daniel S. Contemporary International Relations: Frameworks for Understanding.

United States of America: Allyn and Bacon,h 1997. pages. 442-443 


\section{Discussion}

The United States is one of the countries located on the American continent. It is known as a superpower country due to it's strength in all areas, not only political power but also in the field of army, economy, education, and culture. In addition, religious life in the United States has also displayed a unique figure, all religions with their sect can live in the United States.

In the United States, there are many Sunni, Shiite, Ahmadiyya Muslim communities and so on. ${ }^{32}$ It also determines the policy and politics in the country and abroad the United States itself. The United States of America is a democratic country which is based on individual freedom. It has the intention that the public free decisive political choices religion in the United States.

The United States considers Islam as a threat to world peace. They believe that Islam will win over the West and subject the population of the West to Islam, where the United States believes that this will make the western countries, especially the United States, far from freedom and democracy. Islamic fundamentalism will turn the world into a nuclear war that causes countless deaths, misery and destruction. Therefore, there are opinion that such dangerous religious growth should not be encouraged but be eliminated. In the case of terrorist events, Muslims are the first suspect even when there is no evidence.

In 2009, the United States pew research survey institute surveyed that there were $58 \%$ of US who beliefs that Muslims are the object of discrimination. Furthermore, after the 9/11 attacks, American mainstream views on Muslims continued to be negative below 50 percent and continued to decline. The raising of negative attitude touched its peak in September 2010, at the end of the con controversies "Ground Zero Mosque". This time reflects one of e many events in the past decade that indicate how Islam is seen as not-US and even anti-American. Controversy has a remarkable effect on the entire American project to build a mosque which caused a wave of hatred against individual Muslims, mosques, and Muslim-owned businesses in the United States.

It can be said that the negative and harmful image of Islam in the United States appeared after the tragedy of 911. The stereotype created by the government and leaders of the United States of America made a negative image

\footnotetext{
${ }^{32}$ Husin, "Pendidikan Agama Islam Di Amerika Serikat." Jurnal Ilmiah $A L$ MADRASAH Vol.2, no.2 (Januari-Juni,2018): Pages 1-2.
} 
of Islam, especially for the public. Although there are several sources mentioned that after the tragedy of the 911 indigenous people make quite a lot of the United States. They want to know more about Islam and eventually embraced Islam. Conversely, there are also people and governments of the United States who still do not accept Islam as an accepted religion in the United States.

Indonesia realizes that it is a country whose majority of populations are Muslims. Therefore, Indonesia has a national interest that can bridge the western world especially the United States with Islam. Unfortunately, western countries only knew that Islam is a religion dominated by Arab countries that are principled in terms of Islamic extremism in the western world. The West Valley viewed Islam as a religion that has teaching to ratify and destroy the western world through its action or which is known as jihad in form of terrorism. ${ }^{33}$ It is in line with what happened in the 911 tragedy in the United States, where terrorists from hard-line Islamic groups are suspected to be the terrorist act. Responding this issue, Indonesia considered that Islamophobia has been indoctrinated in particular western countries like the United States by leaders in the United States of America. In the following are Indonesia's national interest in improving the image of Islam in the United States: ${ }^{34}$

1. Indonesia wants to portray and support Indonesia's moderate Islamic values combined with Indonesia's democratic values towards the United States. It was done in order to raise United States' understanding of Islam.

2. Indonesia wants to distinguish Islam in Indonesia from Islam in the Arab countries. Islam in Indonesia is very united with democratic values and not in violence or radical.

3. Indonesia wants to change negative perceptions about Islam in the United States and Indonesia contributes to the creation of world peace as stated in Pancasila, the 1945 Constitution and the National Long-Term Plan.

33 Kementrian Luar Negeri Indonesia,"Rencana Strategis Kementrian Luar Negeri Tahun 2015-2019."2015. page. 9

${ }^{34}$ Bappenas. 2009. "BAB 8 Pemantapan Politik Luar Negeri dan Peningkatan Kerjasama Internasional." accessed www.bappenas.go.id/files/3013/6514/6211/bab8_20090202204616_1756_9.pdf on August 1st, 2019. 
4. Indonesia wants to develop a culture of dialogue, harmony and mutual understanding between religious communities and civilizations in the United States. ${ }^{35}$

Indonesia tried to clarify misconceptions of Western views, especially the United States which claims that the failure of democratic consolidation tends to occur in Muslim-populated countries. ${ }^{36}$ In fact that Indonesia as the Muslim world, clarification then translated overseas development policy to portray itself as a moderate Islam.

The importance of counteracting terrorism by building a moderate Islamic network is recognized by the West by seeing Indonesia as an important actor especially in the Southeast Asian region. With its experience of democracy and moderate Islam, Indonesia is expected to be able to play a role in bridging the between the Islamic world and the West. Holding a role as mediators, Indonesia has sought to demonstrate its existence as an actor in the international area. It cannot be also separated from the perspective of Indonesia to the world that one of its goals is to increase Indonesia's role in the international arena, and its motivation is in line with the principles of inactive foreign policy. Moderate Islam has also become an element of Indonesian foreign policy and it has become an asset of the Indonesian Ministry of Foreign Affairs. Al Busyra Basnur as Director of Political Diplomacy at the Ministry of Foreign Affairs said that moderate Islam is an asset in planning foreign relations, in addition to assets of diversity and artistic and cultural wealth. Busyra also said that it is only in Indonesia, Islam, democracy and modernity can coexist and support each other.

Not only recognition, but moderate imaging of Islamic identity by Indonesia also seems to have received motivation from the West. Rizal Sukma who attended the Wilton Park Conference in England in March 2010, noted that the international community hoped that Indonesia could play its role as the voice of the Islam's world. ${ }^{37}$ This expectation boils down to suggestions

${ }^{35}$ Tabloid Diplomasi. 2013. “Indonesia Prakarsai Interfaith Dialogue.” accessed www.tabloiddiplomasi.org/indonesia-prakarsai-interfaith-dialogue/ on July, 1st, 2019.

${ }^{36}$ Samuel Huntington, Bernard Lewis, "Communism and Islam" dalam Walter Z. Laqueuer (ed), the Middle East in Transition, (New York: Frederick A. Praeger, 1958); dan Ellie Kedourie, Democracy and Arab Political Culture, (Washington DC: Washington Institute for Near East Studies, 1992).

37 Dewi Fortuna Anwar, "Foreign Policy, Islam, and Democracy in Indonesia", Journal of Indonesian Social Sciences and Humanities Vol. 3,( 2010), pages. 38-39. 
that Indonesia can become a mediator between the West and the Islamic world. Therefore, a moderate Islamic Indonesia is also expected to be an alternative model that may be applied to the other community of Muslims. Explicitly, US President Barack Obama said that as Chile and South Korea, Indonesia could be used as a model of democracy is good for Egypt.

To set an alternative Islamic precedent for the Middle East, Indonesia's moderate Islamic foreign policy has substantial capital after the reform. The example is that Indonesia is considered capable of synergizing democratic values with Islam. According to the United States Secretary of State Hillary Clinton, Indonesia is a Muslim country that successfully make the transition from dictatorship to democracy policies. Indonesia must demonstrate to the world that Islam coupled with democracy can also be a positive force participating in solving international problems. Western hopes that Indonesia's moderate Islamic identity can become an alternative model that cannot be separated from the view of many authoritarian regimes in the Islamic world, especially the Middle East and North Africa. In 2010, democracy index issued by the Economist Intelligence Unit, mentioned that these two regions are the most repressive in the world.

The image of moderate Islam in Indonesia was first initiated by the Ministry of Foreign Affairs of the Republic of Indonesia (RI) or has now called the Indonesian Ministry of Foreign Affairs. The ministry's consideration seems to be closely related to the negative stigma of Islam as terrorism which has pushed the Department of Foreign Affairs to show the international world, especially western countries, that Islam which grows and lives in Indonesia is a moderate Islam and not a radical that closely related to anarchism.

Gradually, the term moderate Islam began to be introduced in Indonesian foreign policy. Through oral exposure that started in 2004, Hassan Wirajuda emphasized the obligation of Indonesia as the world's most populous Muslim nation to be able to project the true realm of Islam, Islam as rahmatan lil Alamin. Along with the process of consolidating Indonesia's democracy, the involvement of moderate groups who are non-state actors marked a change in foreign policy patterns. Before Indonesia began the battery consolidation stage of democracy, Indonesia's foreign policy was formulated by the elite rather than through a democratic process. The empowerment of these moderate groups is most likely due to the position of Islam itself. As part of Indonesia's moderate Islamic identity imaging strategy, the government empowers non-governmental actors from moderate Muslim groups. In more detail, groups of Muslims in Indonesia 
have some common characteristics, namely tolerance towards non-Muslim communities and respect for human rights and minorities.

The implementation form of public diplomacy that uses belief as an instrument is interfaith dialogue. In the context of international relations, it must be admitted that some time ago, belief did not receive significant attention, because it was considered as a very private matter and was not related to foreign policy and state policies. It is due to the existence of Westppagesian views in the international community, which later made the Westppagesia Treaty (1648) the basis for a system of international relations. ${ }^{38}$

One side of a person may choose his preferences, and on the other side, it causes the exchange of views and opinions, even friction between each other when coinciding with the interests of the nation, ethnicity, group, economy and so on. In the term of sociology, it is called religious affirmity, which is the closeness of religious activities to certain social identities. ${ }^{39}$ It makes the existence of interfaith dialogue significant to be carried out and become a study. Diplomacy conference managed to be themost beneficial way to improve negotiations between many parties, as well as a driver of bilateral diplomacy, including in the context of interfaith dialogue.

Interfaith dialogue in prizes means interfaith dialogue. There is still no literature defining this phrase terminologically, so the operational definition of this variable still refers to the literal meaning as echoed by Echols. Indonesia is a country that is very concerned about conveying the importance of encouraging interfaith dialogue to achieveharmony among civilization. Interfaith Dialogue is the effort to improve the country's image after the issue of terrorism under the guise of religion, one of the programs implemented by the Indonesian Ministry of Foreign Affairs. This is a significant activity and becomes a part of the Ministry of Foreign Affairs' public diplomacy program. It is considered as an innovation in diplomacy strategies with international and domestic (intermestic) approaches, especially after the emergence of the issue of terrorism.

The interfaith dialogue activity which aims to increase mutual understanding between religions involves various non-state actors such as

${ }^{38}$ Andri Hadi, "Interfaith Dialogue dalam Konteks Hubungan Internasional," Tabloid Diplomasi 15 Juni-14 Juli. 2010. page. 20.

39 M. Atho Mundzar, "Arti Penting Interfaith Dialogue Tidak Perlu Diperdebatkan," Tabloid Diplomasi 15 Juni-14 Juli. 2010. page. 23. 
NGOs, media, religious leaders, and youth. Not only domestic actors, interfaith dialogue was also conducted with governments and communities to embrace actors from other countries. In the international context, the factors driving the emergence of interfaith dialogue include globalization and the rise of religious issues in international relations, the increasing label of Islam as a religion of terrorism, United States unilateralism, and the phenomenon of increasing multi-track diplomacy. Meanwhile, in the domestic realm, the influencing factors are legal constraints and institutional capacity in dealing with terrorism issues, perceptual tensions between the West and Islam, the need to create security and human rights protection, and the need to image Indonesia as the largest Muslim country that is peace and tolerance.

This interfaith dialogue potentially become a soft power for Indonesia. By looking at moderate society, the role of the religious community began to be considered in foreign policy making without reducing the importance of the Pancasila and Law 1945 as the main foundation. The implementation of this interfaith dialogue has contributed to Indonesia's diplomacy. This is an opportunity given to religious leaders to convey the message of peace and help improve the country's image. In addition, with interfaith dialogue, low politics issues such as education, gender, youth and economy become important aspects in responding to terrorism rather than just focusing on military security issues. Another benefit that can be obtained with the use of the interfaith dialogue is an opportunity to expand the network for leaders and religious institutions. Through this effort, communication between the government and the community can be established, both domestically and internationally.

Interfaith dialogue is also Indonesia's contribution for the creation of "harmony among civilizations", which is in accordance with the mandate of the 1945 Constitution, as well as an effort to empower moderates (empowering the moderates) through the development of a culture of dialogue and promotion of harmony between parties of different religions, cultures and backgrounds both behind and between moderate and less moderate groups. In its implementation, the Interfaith Dialogue involved various stakeholders, such as religious leaders, civil society, academics, media, young people, and so on. Through the interfaith dialogue conducted by the two countries, departing from the above, in 2009, Indonesian Foreign Minister and US Foreign Minister Hillary Clinton agreed to work together thoroughly for the two countries. L pestle in 2010 the Ministry of Foreign Affairs of the Republic of Indonesia to cooperate with the United States Department of State 
hosted the Indonesia-US Interfaith Cooperation (cooperation interfaith Indonesia-United States), this cooperation is the theme of Building Collaborative Communities: Enchancing Cooperation among People of Different Faiths. In this collaboration dialogue event, the Indonesian delegations led by the Director General of Information and Public Diplomacy of the Indonesian Ministry of Foreign Affairs Andri Hadi, including 30 people that consists of representatives of interfaith leaders, NGOs, academics, media, and officials from the Ministry of Foreign Affairs and the Ministry of Religion.$^{40}$

On this occasion, the government of Indonesia and the United States brought together figures from various religious and religious backgrounds as well as academics to discuss several issues become common problems. Points that were discussed are the cooperation in empowering the moderates, in overcoming negative stereotypes, promote harmony between civilizations, and enhance cooperation in education and government, as well as answering the challenges to global issues such as poverty and climate change.

\section{Conclusion}

Grounded to the results and discussion of this research, it can be concluded that Indonesia wants to change the negative perception of Islam in the view of the United States. Moreover, Indonesia wants to participate in creating world peace as stated in the Pancasila, 1945 Constitution and the National Long-Term Plan. Indonesia's moderate Islamic foreign policy is the initial foundation for achieving Indonesia's national interests to improve the image of Islam in the view of the United States. Interfaith Dialogue conducted by Indonesia against the United States from 2010-2017 is the output of Indonesia's moderate Islamic foreign policy. Interfaith dialogue is an effort of Indonesia in the form of religious diplomacy to improve the image of Islam towards the Islamic view of the United States. In its dynamics, the Interfaith Dialogue conducted by Indonesia against the United States is not only carried out by state actors such as the Ministry of Foreign Affairs, and the Indonesian Ambassador to the United States but also uses all its soft power elements, namely non-governmental actors such as Indonesian religious leaders of different religions.

Establishing bilateral relations between Indonesia and the United States, the United States now recognizes that Islam can be integrated with

${ }^{40}$ Nasional Kompas, 2010. "Indonesia-AS Adakan Kerja Sama Lintas Agama accessed https://nasional.kompas.clom/read/2010/01/25/14043756/Indonesia-AS. Adakan. Kerja.Sama.Lintas.Agama on July 26th, 2019 
democracy and other religions such as those in Indonesia. Indonesia succeeded in its efforts to improve its image of the United States by distinguishing Indonesian Islam that is tolerant and different from Islam in other Middle Eastern countries. Proven in 2016, Indonesia and the United States agreed to establish a program of tolerance and pluralism between religions under the auspices of NGOs made by the United States and Indonesia, namely USINDO. Then in 2017, United States vice president Mike Pence paid a visit and conducted an Interfaith Dialogue with Islamic leaders at the Istiqlal Mosque. This great event changed the view of the United States regarding Islam, Mike Pence said he would imitate and apply religious tolerance in the United States in the future as Indonesia did.

\section{References}

Andriasanti, Lelly. "Moderate Islamic Identity in Indonesian Foreign Policy." Global: Universitas August 1945 Jakarta Paper.Vol. 16 No. 1 (2014).

Anthonius Sitepu, P. International Relations Study. Yogyakarta: Graha Science, 2011.

Anwar, Fortuna Dewi. "Foreign Policy, Islam, and Democracy in Indonesia", Journal of Indonesian Social Sciences and Humanities Vol. 3 , (2010): 38-39.

Bappenas. 2009. "CHAPTER 8 Strengthening Politics Outside Foreign Affairs and Improving International Cooperation." www.bappenas.go.id/files/3013/6514/6211/bab-

8_20090202204616_1756_9.pdf on August 1st, 2019.

Djelantik, Sukawarsini. Diplomacy: Between Theory and Practice. Yogyakarta: Graha Science, 2008.

Embassy of Indonesia. "Brief History of Bilateral Relations of the United States and Indonesia". www.embassyofindonesia.org/index.php/bilateralrelations/ on July 30th 2019.

Falahi, Ziyad. "Significance of Moderate Islamic Diplomacy in the Era of Susilo Bambang Yudhoyono in Responding to Middle East Problems." Andalas Journal of International Relations No.1 Vol.2, (2013): 33.

Freeman, Chas. The Diplomat's Diary, National Defense: University Press. 2006. accessed via https: // e- journal.unair.ac.id/JGS/article/view/6915 on Wednesday 11 December 2018. 
18 | AJIS : Academic Journal of Islamic Studies, vol. 5, no. 1, 2020

Hadi, Andri. "Interfaith Dialogue in the Context of International Relations.” Diplomacy Tabloid . June 15-July 14, 2010.

Harison, Lisa. Political Research Methods, Jakarta: Kencana, 2007.

Husin, "Islamic Education in the United States." AL-MADRASAH Scientific Journal Vol.2, no.2 (January-June , 2018 ): 1-2.

J.Moleong, Lexy. Qualitative Research Methodology, Bandung: PT. Rosdakarya teenagers. Cet 33, 2014.

Khotimah, Ema. "Ideological Bias and Religious Prejudice in Terrorism and Mass Media." Journal of Religion: Vol. XIX No. 04, (2003): 347-350.

Lewis, Bernard and Samuel Huntington. "Communism and Islam" in Walter Z. Laqueuer (ed), the Middle East in Transition, (New York: Frederick A. Praeger, 1958); and Ellie Kedourie, Democracy and Arabic Political Culture, (Washington DC: Washington Institute for Near East Studies, 1992).

Ministry of Religion. "Rationale for Interfaith Dialogue." Accessed via https://pkub.kemenag.go.id/artikel/17866/dasar-pemikir-interfaithdialogue on Monday, June 17th, 2019.

Ministry of Foreign Affairs. "Bilateral Relations between Indonesia and the United States.”, https://kemlu.go.id/washington/id/pages/h Relations_bilateral/554/etc- menu on Monday, June 17th, 2019.

Ministry of Foreign Affairs. "RI-US Agree on Peace Corps and Interfaith Dialogue Collaboration.”, https://ex.kemlu.go.id/id/id/berita/siaranpress/Pages/RI-AS-Agree-Cooperation-i-Peace-Corps-and-InterfaithDialogue-i.aspx on Monday, June 17, 2019.

Ministry of Foreign Affairs of Indonesia, "Strategic Planning of the Ministry of Foreign Affairs in 2015 - 2019.” 2015.

Moordiningsih, "Islamophobia and Strategies to Overcome It." Psychology Bulletin: Year XII No.2, 2004.

Much. Yati, Abizal. “Islam and World Peace.” Islam Futura: Vol. VI No.2, (2007): 13.

Mundzar, M. Atho. 2010. “The Importance of Interfaith Dialogue Does Not Have to Be Debated," Diplomacy Tabloid June 15-July 14.

Mas'oed,Mochtar. International Relations: Discipline and Methodology. Jakarta: LP3ES, 1990. 
Muttaqien, Muhammad. Strategic Study Indonesia II: Foreign Policy of the Republic of Indonesia.

Mutholib A, Abdul. “China's Interest in the Syrian Conflict. Skripi, Sulawesi: Hasanudin University, 2013.

Nasional Kompas, 2010. "Indonesia-US Holds Interfaith Cooperation", https: //nasional.kompas.clom/read/2010/01/25/14043756/IndonesiaAS.Adakan.Kerja.Sama.Lintas.Rama at July 26, 2019.

Olton, Roy and Jack C. Plano. Dictionary of International Relations Bandung: Abardin, 1999.

Purwono, Andi. "International Religious and Security Organization: Some Principles and Practices of Indonesian Nahdlatul Ulama (NU) Diplomacy." Journal of Prophetic Politics : Vol. 2 No.2, (2013): 1.

Subehan, Kpagesik. "History of the Development of Islam in America." Al Daulah : Vol. 4 No.2, (2015): 317.

Sukma, Rizal. Islam in Indonesian Foreign Policy. Routledge Curzon.

S, Daniel and Papp. Contemporary International Relations: Frameworks for Understanding . United States of America: Allyn and Baconh, 1997.

Suryana, Jaka Mirza and Asrudin. Reflections on International Relations Theory from Traditional to Temporary, Yogyakarta: Graha Science, 2009.

Tabloid Diplomacy. 2013. “Indonesia Initiates Interfaith Dialogue.” Accessed via www.tabloiddiplomasi.org/indonesia-prakarsai-interfaith- dialogue / on July 1, 2019.

Tontowi, Jawahir "President Trump's policy and his community's response to the Prohibition of Arab Muslims Living in America." IUS QUIA IUSTUM Law Journal No. 3 Vol. 24, (2017): 378.

Winingsih, Sri. "US Foreign Policy Towards Iran's Nuclear Program," Thesis, West Java : University of Indonesia, 2009 
20 | AJIS : Academic Journal of Islamic Studies, vol. 5, no. 1, 2020

This page is empty 